\title{
EXAMINE OF THE IMPACT OF LAND USE ON WATER BASINS USING GEOGRAPHICAL INFORMATION SYSTEMS AND REMOTE SENSING: TERKOS BASIN EXAMPLE
}

\author{
S. AHï ${ }^{1}$, A. EYMEN ${ }^{2, *}$ \\ ${ }^{1}$ Graduate School of Natural and Applied Sciences, Geomatic Engineering, Erciyes University, Kayseri, Turkey - \\ senaahi97@gmail.com \\ ${ }^{2}$ Engineering Faculty, Geomatic Engineering, Erciyes University, Kayseri, Turkey - ageymen@erciyes.edu.tr
}

KEY WORDS: Remote Sensing, Geographic Information Systems, Basin, Satellite Images

\begin{abstract}
:
Development movements bring along population movements. Investments in Istanbul make the city of Istanbul even more attractive. With the increasing population, the need for water is increasing day by day. Construction of the 3rd Istanbul Airport within the borders of Terkos Basin, which is one of the important drinking water resources of Istanbul, has caused land use changes in the basin. Geographical Information Systems (GIS) and Remote Sensing techniques have been used to examine this change. The data obtained through Remote Sensing can be easily analyzed in GIS environment.

In this study, Landsat 8 satellite images of the years 2013, 2015 and 2020 were preferred in the examination of the temporal change of land use of the Terkos Basin. The satellite images obtained were classified using the controlled classification technique in the Envi program. Satellite images classified for the creation and analysis of land use maps have been transferred to the ArcGIS program. The changes in the classes determined according to the obtained results were examined, and the changes in question were revealed by spatial analysis. Suggestions have been made for the protection of the Terkos drinking water basin and ecosystem, which is extremely important for Istanbul.
\end{abstract}

\section{INTRODUCTION}

With the ever-increasing world population, the needs of individuals have increased and this increasing population has led to changes in land use patterns (Kaşıkçı et al., 2020). As the needs increased, the demand for water and water resources increased accordingly. With this increasing demand, water resources are being consumed unconsciously, so the resources become polluted quickly. This situation creates an obstacle to access to quality and sufficient drinking water. Providing watershed management is of great importance in order to solve these problems and ensure sustainability. One of the important issues to ensure sustainability along with urban development is the preparation of a land use plan (Torun, 2008; Özonat, 2017).

Today, changes in water resources can be determined more quickly and economically with the advantages provided by remote sensing and geographic information systems. With the use of remote sensing and GIS in the efficient management of water resources; time-dependent changes in land use can be determined quickly, the results obtained are presented with thematic maps and future protection plans can be created (Erdoğan et al., 2014).

Remote Sensing and GIS, which are fast and reliable techniques, have led to detailed studies in determining land use change on watersheds (Wu et al., 2006; Shalaby and Tateishi, 2007; Dewan and Yamaguchi, 2009; Gürbüz et al., 2012; Kara and Karatepe, 2012).

The temporal change can be determined with the help of two or more satellite images. In order for the result to be obtained from the satellite image to be meaningful, care should be taken to ensure that the image to be selected is cloudless and clear (Kara and Karatepe, 2012).

The basin area is affected not only by natural factors such as rain, water resources, erosion, but also by the wrong land use around it (Bozyiğit and Kaya, 2019). Failure to provide urban development control around water basins leads to a decrease in forest and similar natural resources, and an increase in settlement areas. Such a transformation causes faulty land use (Geymen, 2017). In other words, settlement areas that develop without borders pose a problem for the basins. (Duran and Günek, 2007).

The basin is not just a water area, it also contains the environment it interacts with (Yamaç Yükrük, 2019). In other words, any change in the basin ecosystem also affects the other interaction areas (Yamaç Yükrük, 2019). Determination of land use status for basins; It will contribute to the development of decisions to be made for the sustainability of the city and to make predictions about the future (Dewan and Yamaguchi, 2009). In such studies, remote sensing techniques are used to monitor changes due to land use, while geographic information systems are used to make spatial analysis of land use. The studies in which these two systems are used together are increasing day by day (Bahadır, 2013).

The province of Istanbul is an important air transport network center due to its location. With the increasing need, the 3rd Istanbul Airport was built. A part of the 3rd Istanbul Airport built is located within the borders of Terkos Basin. Therefore, it is of great importance to examine the effects of a study that changes the land cover, such as an airport, on the basins. (Uça Avcr and Sunar, 2018).

\footnotetext{
* Corresponding author
} 
In this study, by using Remote Sensing and GIS integration together, Landsat satellite images of the past years were classified with appropriate classification techniques in order to determine the land use change of the Terkos basin in the province of Istanbul.

\section{MATERIALS AND METHODS}

\subsection{Study Area}

Terkos Basin, which is determined as the study area, is a basin built in 1883 in the district of Çatalca, on the west of Istanbul, on the coast of the Black Sea (Yün, 2009; Bayram et al., 2013). There are Alibeyköy and Küçükçekmece basins in the southeast of the basin, and Büyükçekmece basin in the south (Özkan Y1lmaz, 2008).

Terkos Basin, which has the largest area among Istanbul water collection basin areas, is one of the most important drinking water suppliers (Özkan Yılmaz, 2008; Bektaş Balçık and Göksel). It is also the drinking water basin with the largest forest area among the water basins in Istanbul (Özkan Y1lmaz, 2008; Yamaç Yükrük, 2019). Excess forest areas in the basin are a factor that positively affects the urban ecosystem as it reduces air pollution (Özkan Yılmaz, 2008).

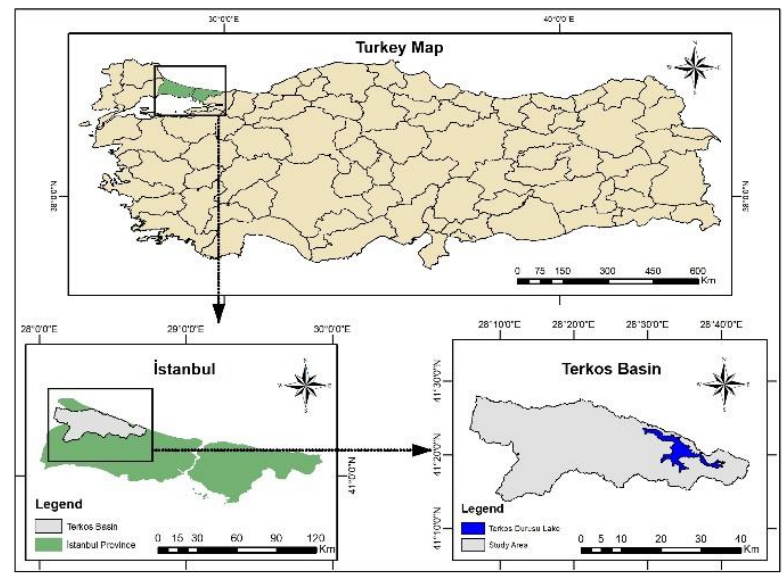

Figure 1. Study Area

\subsection{Study Data}

In this study, Landsat-8 satellite images of 2013, 2015 and 2020 were used to examine the change in Terkos Basin due to land use. Satellite images were obtained from USGS Earth Explorer. Obtained satellite images are in UTM projection and WGS84 datum. Within the content of the study, Envi 5.3 software was used in the application part and ArcGIS 10.3 software was used in the visualization of the results. Satellite images of the years used to classify the Terkos Basin are presented in Figure 2.

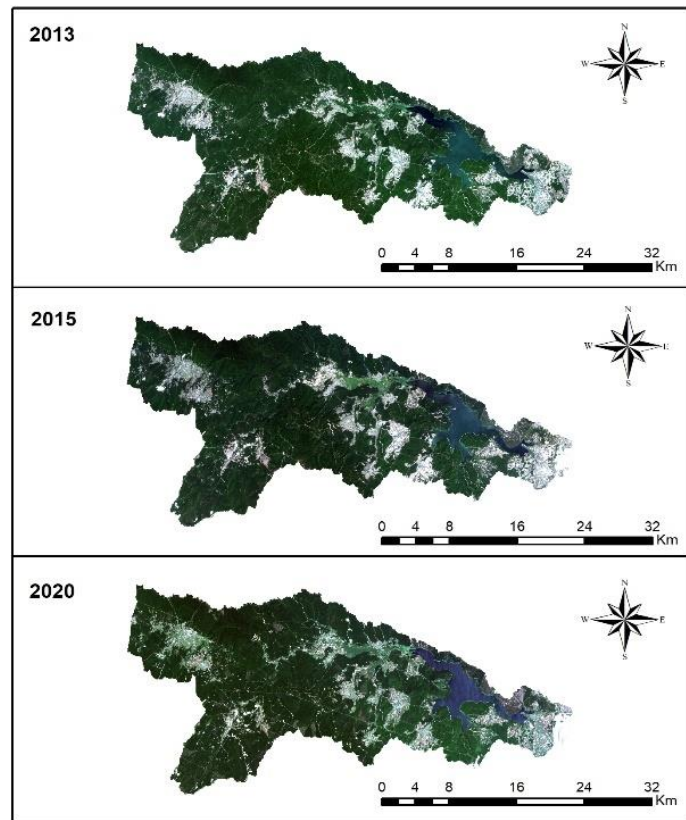

Figure 2. Satellite Images

\subsection{Method}

In this study, primarily satellite images were obtained to examine the changes in land use in the Terkos Basin in the province of Istanbul. After the satellite images were edited, the images obtained were classified with the controlled classification technique and the changes were revealed after the accuracy analysis was done.

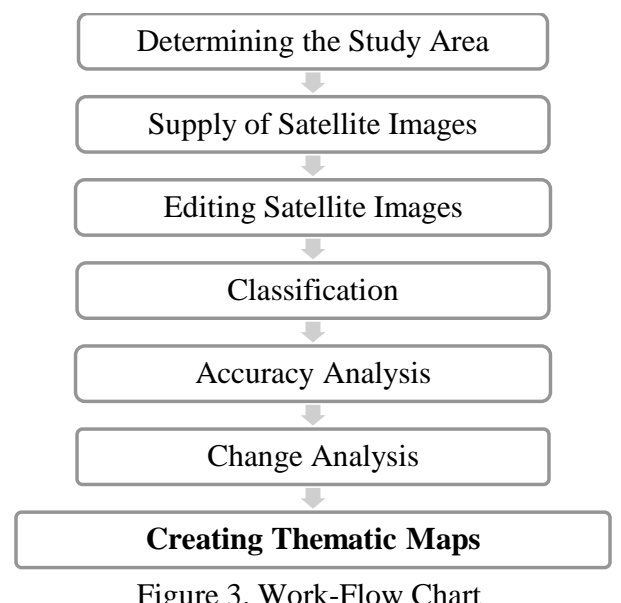

\subsection{Classification}

Image classification can be defined as the process of collecting pixels with different spectral characteristics into classes according to their properties (Siewe, 2007). Classification of satellite images is a common method used to extract meaningful information from raw data (Güney and Ölgen, 2009; Temiz, 2017). The purpose of the classification process is to group together objects with the same spectral characteristics. (Temiz, 2017). Image classification can be done in two different ways: controlled classification and uncontrolled classification.

In this study, classification was made with the controlled classification technique. Support Vector Machines method was used in controlled classification. 


\subsection{Accuracy Analysis}

Accuracy analysis should be performed to determine the accuracy of the result obtained after the classification process (Güney and Ölgen, 2009). The purpose of classification accuracy is to demonstrate the correspondence between the class label assigned to a pixel and the actual ground surface. The real earth surface can be observed directly or indirectly from satellite images or existing map plans (Göksel, 1996).

In order to check the accuracy of classification processes, statistical comparison of pixel values with reference satellite images, maps or real ground surface is made. The most common approach used to determine the error measure as a result of the comparison is the error matrix approach. Error matrix is obtained by placing classified data in rows and reference data in columns. The overall accuracy is obtained by dividing the correctly classified pixels by the total number of pixels checked (Banko, 1998).

Another accuracy criterion produced by the error matrix is the kappa value. This value is an accuracy measure using all elements. Kappa statistic, which takes a value between $0-1$, is calculated with the help of the row-column sums in the error matrix and the apples on the diagonal. If the obtained value is greater than 0.8 , it is concluded that the study is successful (Gürbüz et al., 2012). In addition, if the overall accuracy value is above $80 \%$, the classification is considered reliable (Güney and Ölgen, 2009).

In this study, error matrix approach was used for postclassification accuracy analysis.

\section{RESULTS}

\subsection{Land Use Status of Terkos Basin in 2013-2015-2020}

The number of classes used to classify the Terkos Basin is 6 . These classes were determined as water area, residential, forest, agricultural-grassland area, light soil, dark soil. Groups of pixels with similar properties were assigned to the same class. In other words, areas such as roads and airports are included in the residential class. Land use maps were created by classifying the satellite images obtained according to the years with the controlled classification technique. The obtained land use maps of 2013, 2015 and 2020 are presented in Figure 4. According to the results obtained, the total area of the basin corresponds to 73,613.52 hectares. A large part of this area consists of forest area.

When the area table given in Table 1 is examined, it has been observed that there has been a decrease in all classes except for residential and light soil class from 2013 to 2020. The residential areas, which constituted $1.47 \%$ of the total area with 1084.23 hectares in 2013, reached 1659.51 hectares in 2020 and covered $2.25 \%$ of the total area. The biggest change in the basin borders has been in the residential class. Although the forest areas first decreased and then increased from 2013 to 2020, while it covered 54750.24 ha in 2013, the area it covered decreased to 54697.32 hectares in 2020. It is thought that the lost forests can be regained by making more afforestation works. Agricultural-grassland areas are constantly showed a decreasing trend. While it covered an area of $17.33 \%$ proportionally with 12754.89 hectares in 2013 , it decreased to $16.65 \%$ proportionally with 12258.18 hectares in 2020. Although there was no significant decrease in the water area, the area covered decreased from 3203.64 hectares to 3119.13 hectares.
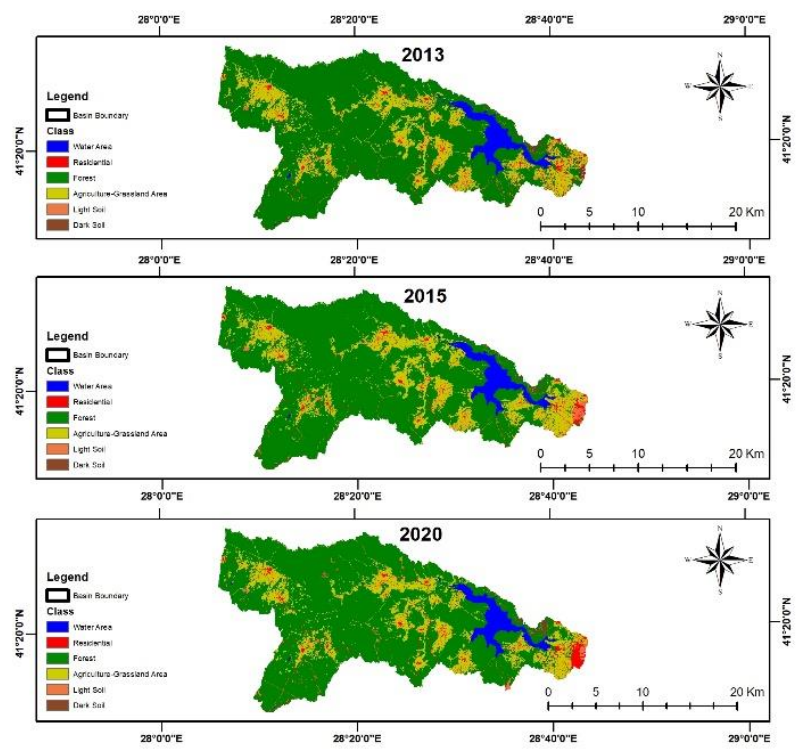

Figure 4. Land Use Maps

\begin{tabular}{|ccccccc|}
\hline Class & \multicolumn{2}{c}{2013} & \multicolumn{2}{c}{2015} & \multicolumn{2}{c|}{2020} \\
& $\begin{array}{c}\text { Area } \\
(\mathbf{H a})\end{array}$ & $\begin{array}{c}\text { Rate } \\
(\boldsymbol{\%})\end{array}$ & $\begin{array}{c}\text { Area } \\
(\mathbf{H a})\end{array}$ & $\begin{array}{c}\text { Rate } \\
(\boldsymbol{\%})\end{array}$ & $\begin{array}{c}\text { Area } \\
(\mathbf{H a})\end{array}$ & $\begin{array}{c}\text { Rate } \\
(\mathbf{\%})\end{array}$ \\
Water Area & 3203.64 & 4.35 & 3122.64 & 4.24 & 3119.13 & 4.24 \\
Residential & 1084.23 & 1.47 & 1218.69 & 1.66 & 1659.51 & 2.25 \\
Forest & 54750.24 & 74.37 & 54584,64 & 74.15 & 54697.32 & 74.30 \\
$\begin{array}{c}\text { Agricultıre- } \\
\text { Grassland }\end{array}$ & 12754.89 & 17.33 & 12701,97 & 17.25 & 12258.18 & 16.65 \\
\hline Light Soil & 1090.71 & 1.49 & 1447,38 & 1.97 & 1454,31 & 1.98 \\
Dark Soil & 729.81 & 0.99 & 538,20 & 0.73 & 425.07 & 0.58 \\
Total & $\mathbf{7 3 6 1 3 . 5 2}$ & $\mathbf{1 0 0}$ & $\mathbf{7 3 6 1 3 . 5 2}$ & $\mathbf{1 0 0 . 0 0}$ & $\mathbf{7 3 6 1 3 . 5 2}$ & $\mathbf{1 0 0 . 0 0}$ \\
\hline
\end{tabular}

Table 1. Land Use Distribution

\subsection{Accuracy Analysis Results}

In this part of the study, the general accuracy and kappa values obtained as a result of the accuracy analysis after classification are presented. When the data presented in Table 2 are examined, it is seen that the accuracy levels obtained in each year of the study are above the reliable value.

\begin{tabular}{ccc}
\hline Year & Overall Accuracy (\%) & Kappa (\%) \\
\hline $\mathbf{2 0 1 3}$ & 89.17 & 86 \\
\hline $\mathbf{2 0 1 5}$ & 88.72 & 85 \\
\hline $\mathbf{2 0 2 0}$ & 88.95 & 86 \\
\hline
\end{tabular}

Table 2. Accuracy Analysis Results 


\subsection{Change Analysis}

Changes in the 6 classes determined in the study area were created with change detection statistics in the Envi program based on the areas. In this section, the changes that took place from 2013 to 2020 are presented. Figure 5 shows the data for 2013 and 2020 comparatively. When the trends of land use classes determined between 2013 and 2020 are examined, it is observed that there is a decrease in the classes that are important for the ecosystem.

From 2013 to 2020, the residential class has always shown an increasing trend. The initiation of airport construction works in 2015 and its active use in 2020 are among the most important factors driving this increase. From 2013 to 2020, residential areas increased by $53.06 \%$. Although the biggest reason for this increase rate is the airport, the effect of the increasing population is also great. The fact that the airport is within the borders of the basin has drawn the mobility to the northern part of the city. It is thought that human activities due to the concentration of mobility around the basin may cause pollution of the basin. Despite the decrease in water area in the basin, no significant change has occurred. From 2013 to 2020 , the water area decreased by $2.64 \%$. This decrease is thought to be due to the effect of natural factors as well as the effect of human factors. With the changing climatic conditions, less rainfall causes the basin water to be withdrawn.
From 2013 to 2020 , there have been was a $0.10 \%$ decrease in forest areas. According to the data given in Table 1, the forest areas, which decreased with the start of airport works from 2013 to 2015 , started to be recovered with afforestation activities in the period between 2015-2020. Although there has been a decrease in the forest class from 2013 to 2020, it is thought that this decrease can be compensated with the number of afforestation.

It has been observed that there has always been a decrease in the agricultural-grassland class throughout the period. Agriculturalgrassland areas decreased by $3.89 \%$ from 2013 to 2020 . This decrease is due to the presence of agricultural lands in 2013 at the site of the airport. Some of the lost agricultural-grassland lands have been replaced by residential areas.

To summarize, from 2013 to 2020, the water area decreased by $2.64 \%$, the forest area by $0.10 \%$, the agricultural-grassland class by $3.89 \%$, the dark soil class by $41.76 \%$, while the residential area increased by $53.06 \%$ and the light soil group by $33.37 \%$.

\section{3-2020 Terkos Basin Area Comparison (Ha)}

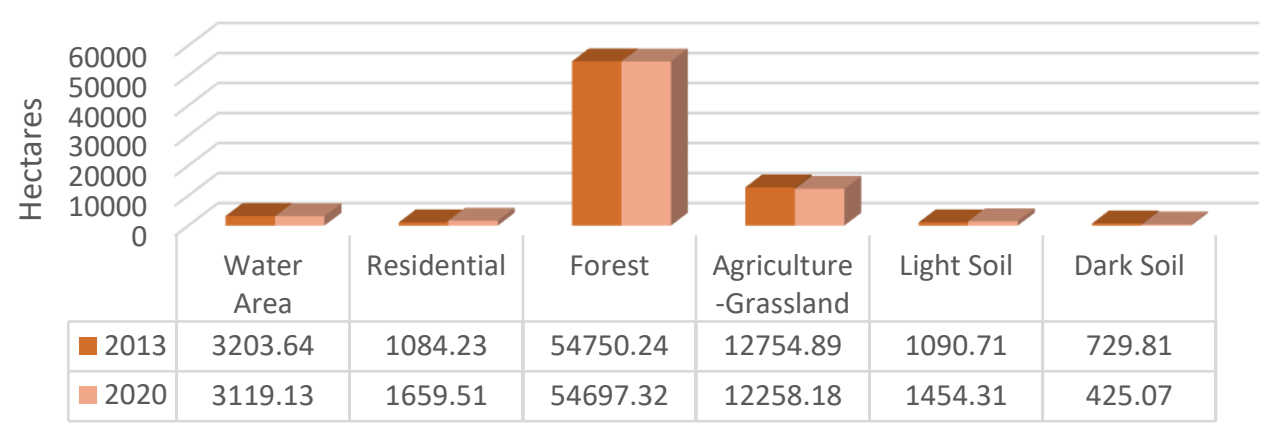

Land Use Classes

Figure 5. 2013-2020 Area Comparison

\begin{tabular}{|c|c|c|c|}
\hline Class / Year & 2013 & 2020 & Change \\
\hline Water Area & $3.203,64$ & $3.119,13$ & $-84,51$ \\
\hline Residential & $1.084,23$ & $1.659,51$ & 575,28 \\
\hline Forest & $54.750,24$ & $54.697,32$ & $-52,92$ \\
\hline Agriculture-Grassland & $12.754,89$ & $12.258,18$ & $-496,71$ \\
\hline Light Soil & $1.090,71$ & $1.454,31$ & 363,6 \\
\hline Dark Soil & 729,81 & 425,07 & $-304,11$ \\
\hline
\end{tabular}

Table 3. Area Change 


\section{CONCLUSION}

Within the scope of this study, Landsat- 8 satellite images of 2013, 2015 and 2020 belonging to Terkos Basin were classified by controlled classification, post-classification accuracy analyzes were made with error matrix approach and the changes in the classes were revealed. When the results of the classification process were examined, it was seen that the construction of the 3rd Istanbul Airport within the borders of Terkos Basin caused changes in land use. According to the results of the study, no major change was observed for Terkos lake. However, it is foreseen that the large increase in the residential areas may lead to a decrease in the water area unless measures are taken. It is thought that there is a need for applicable planning both to prevent the human factors affecting the decrease in water and to keep the water clean.

It is expected that this study, which is carried out with the help of Remote Sensing and GIS techniques, will help protect the water basins, which are of great importance for Istanbul, while making future plans. It will be of great benefit in preventing the problems that may arise after the development activities arising from the increasing need are followed and carried out within a plan. While making plans, policies for the protection of nature should be followed.

\section{REFERENCES}

Bahadır, M., 2013. The natural conditions of the Iş1klı Lake Watershed and its reflection on Land Use. Istanbul University Faculty of Letters Department of Geography Journal of Geography, 0(26), 1-20.

Banko, G., 1998. A review of assessing the accuracy of classifications of remotely sensed data and of methods including remote sensing data in Forest Inventory, Interim Report, IR-98081, November.

Bayram, B., Seker, D. Z., Acar, U., Yuksel, Y., Guner, H. A. A., Cetin, I., 2013. An integrated approach to temporal monitoring of the shoreline and basin of Terkos Lake. Journal of Coastal Research, 29(6), 1427-1435.

Bektaş Balçık, F., Göksel, Ç., 2012. Determination of magnitude and direction of land use / land cover changes in Terkos Water Basin, İstanbul. XXII ISPRS Congress, 25 August-01 September, 2012, Melbourne, Australia.

Bozyiğit, R., Kaya, B., 2019. Land Use in Altınapa Dam Basin (Konya). European Journal of Science and Technology, No.16, pp. 688-700.

Dewan, A. M., Yamaguchi, Y., 2009. Land use and land cover change in greater Dhaka, Bangladesh: Using remote sensing to promote. Applied Geography, 29(3): 390-401.

Duran, C., Günek, H., 2007. Determination Land Use Changing in Basin of Lake of Hazar (1956-2004). Firat University Journal of Social Science, 17(2): 31-52.

Erdoğan, M. A., Sönmez, F., Berberoğlu, S., 2014. The estimation and monitoring of dam lake water level with the support of remote sensing and GIs: In the case of Adana Seyhan Dam Lake, 5. Remote Sensing - GIS Symposium, 14-17 October, 2014, Istanbul.
Geymen, A., 2017. Monitoring of environmental impacts and land-use changes in water basin using Geographical Information Systems: Elmalı Basin Case Study. Ĭgdır University Journal Institute Science \& Technology, 7(1): 171-181.

Göksel, Ç., 1996. Observation by Remote Sensing Data of Elmali and Alibey Water Basin Area and Realisation of Information System. İstanbul Technical University, Institution of Science and Technology, PhD Thesis, p.148.

Güney, Y., Ölgen, M. K., 2009. Determination of land use change in Bornova using landsat satellite images. pp.93-104. 3.DEU GIS Symposium, 10-11 December, 2009, İzmir.

Gürbüz, M., Denizdurduran, M., Karabulut, M., Kızılelma, Y., 2012. Investigation of land use / land cover changes by using remote sensing and GIS in Elbistan Plain. KSU Journal Engineering Science, Special Edition:30-37.

Kara, F., Karatepe, A., 2012. Land use change analysis of Beykoz District (1986-2011) with remote sensing technologies. Marmara Geography Journal, (25): 378-389.

Kaşıçc, Z., Çelik, N., Sarıyılmaz, F. B., 2020. Determination of land use and land cover change with time series images: Elmal Basin, Istanbul. Turkish Journal of Remote Sensing, 2(1): 16-21.

Özkan Y1lmaz, S., 2008. Determining The Criteria for Using Protection in Water Basins; Example Of Lake Terkos. Y1ld1z Technical University, Institution of Science and Technology, Master Thesis, Istanbul, p.253.

Özonat, Ç., 2017. Evaluation of the Effects of Land Use Changes on Drinking Water Basins: The Case of Elmali Dam Lake. T.R. Forest and Water Job Ministry, Master Thesis, Ankara, p.158.

Shalaby, A., Tateishi, R., 2007. Remote sensing and GIS for mapping and monitoring land cover and landuse changes in the northwestern coastal zone of Egypt. Applied Geography, 27(1): $28-41$.

Siewe, S. S., 2007. Change Detection Analysis Of The Landuse and Landcover of The Fort Cobb Reservoir Watershed. Oklahoma State University, Master of Science, USA, 86s.

Temiz, F., 2017. Analysing Land Use / Cover Change Using Remote Sensing and GIS Techniques: A Case Study of Denizli, Turkey. Necmettin Erbakan University, Institution of Science and Technology, Master Thesis, Konya, p.115.

Torun, G., 2008. Basin Planning and Management in The Context of Sustainable Development: The Case of Alibey Drinking Water Basin. Mimar Sinan Fine Arts University, Institution of Science and Technology, Master Thesis, p.228.

Uça Avc1, Z. D., Sunar, F., 2018. Use of object-based landcover/land use change detection analysis: Istanbul's 3rd Airport. Remote Sensing - GIS Symposium, 18-21 September, 2018, Eskişehir.

Wu, Q., Li, H., Wang, R., Paulussen, J., He, Y., Wang, M., Wang, Z., 2006. Monitoring and predicting land use change in Beijing using remote sensing and GIS. Landscape and Urban Planning, 78(4): 322-333. 
Yamaç Yükrük, Z., 2019. An Evaluation About the Changes of Istanbul's Water Basins. Y1ldiz Technical University, Institution of Science and Technology, Master Thesis, p.204.

Yün, M., 2009. Basin Planning and Management: Example of Ömerli Basin. Mimar Sinan Fine Arts University, Institution of Science and Technology, Master Thesis, p.178. 